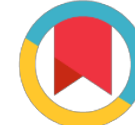

Check for updates

*For correspondence:

mylene.uy@g.msuiit.edu.ph

Competing interests: The authors declare that no competing interests exist.

Received: 2017-04-30

Accepted: 2017-06-04

Published: 2017-09-05

Copyright The Author(s) 2017. This article is published with open access by BioMedPress (BMP).

This article is distributed under the terms of the Creative Commons Attribution License (CC-BY 4.0) which permits any use, distribution, and reproduction in any medium, provided the original author(s) and the source are credited.

\section{Cytotoxic activities of Philippine marine sponges against colon cancer cells}

\author{
Mylene Uy, Hendrik Luesch \\ Department of Chemistry, Mindanao State University-Iligan Institute of Technology \\ Andres Bonifacio Avenue, Iligan City, Lanao del Norte 9200, Philippine
}

\section{Abstract}

Although the diversity of life in the terrestrial environment is exceptional, the greatest biodiversity is in the marine environment. Among the marine organisms, the sponges (Porifera) are the most prolific sources of bioactive secondary metabolites. The Philippines, with its long coastal lines, has drawn on its marine capital only to a small extent. Only a few marine organisms (ascidians, sponges, other marine invertebrates and their associated microorganisms) collected from various parts of the Philippines have been documented and investigated in terms of their potential as source of bioactive secondary metabolites, particularly anticancer compounds. Thirty-seven sponges from the coasts off Mindanao, Philippines were collected, identifies and extracted to give a total of seventy-four polar and nonpolar extracts. The corresponding sponge extracts were screened for the sponge extracts were investigated for cytotoxicity towards colon cell lines $\left(\mathrm{HCT}_{116}\right)$ using the the tetrazolium dye $\left(3-\left(4,5^{-}\right.\right.$ Dimethylthiazol-2-yl)- 2,5- diphenyltetrazolium bromide) [MTTmethod. The results indicated fifteen (15) sponge extracts to be active at 100- microgram $/ \mathrm{mL}$ concentration among which seven (7) were still active at 10 microgram $/ \mathrm{mL}$ while two (2) still exhibited activity at 1 microgram $/ \mathrm{mL}$. Further investigation of the active sponge extracts is currently in progress.

\section{Keywords}

marine sponges, cytotoxic, colon cancer cell line, MTT

Funding

Department of Science and Technology-Philippine Council for Health Research and Development

References 